Review Article

\title{
Towards Adoption of Constructivist Instructional Approach in Learning Biology in Secondary School Students in Kenya: Addressing Learner Attitude
}

\author{
Gideon Mwanda ${ }^{1}$, Paul Odundo ${ }^{2}$, Ronnie Midigo ${ }^{3}$ \\ Department of Education Technology, University of Nairobi, Nairobi, Kenya \\ Email address: \\ mwandagideon@yahoo.com (G. Mwanda),odundopaul@yahoo.com (P. Odundo),ronniemidigo@gmail.com (R. Midigo)
}

\section{To cite this article:}

Gideon Mwanda, Paul Odundo, Ronnie Midigo. Towards Adoption of Constructivist Instructional Approach in Learning Biology in Secondary School Students in Kenya: Addressing Learner Attitude. International Journal of Secondary Education. Vol. 5, No. 1, 2017 , pp. 1-11. doi: $10.11648 /$ j.ijsedu.20170501.11

Received: August 13, 2016; Accepted: August 27, 2016; Published: February 21, 2017

\begin{abstract}
Learning Biology helps learners to acquire requisite knowledge in understanding life processes for positive coexistence. In instances where learners appreciate the position of biology in life, they develop positive attitude and this is reflected in their performance. However, in Kenya, most students have continued to register poor performance in biology in national examinations and this has been attributed to negative attitude towards the sciences by most learners. To address this, changes in the educational curricula and teaching methods from the transmission curriculum to a transactional curriculum has been suggested. The changes imply adjustments in the instructional process to include learner centred activities. On the other hand, studies have shown that the attitude of learners towards changes influence the adoptability and workability of the introduced change. This study investigated attitude of learners towards the constructivist instructional approach. The study adopted a cross-sectional survey technique. Data was obtained from four boys', four girls', and four mixed secondary schools with a total of 477 students and were analysed using both descriptive and inferential statistics. The results indicated that learners have positive attitude towards the constructivist instructional approach. Boys obtained a scores of $(\mathrm{M}=58.30 ; \mathrm{SD}=9.15, \mathrm{~N}=150)$ while girls had a score of $(\mathrm{M}=53.14 ; \mathrm{SD}=8.24, \mathrm{~N}=146)$. Based on this finding, it is recommended that instructors adopt the constructivist approach in learning so as to boost the attitude of students towards learning biology. It would also be appropriate for further investigations to be conducted in other fields of science such as chemistry and Physics so as to find out if the constructivist approach would also boost the attitude of students in such subjects. Finally, policy makers in the field of education in Kenya (The Ministry of Education, Science and Technology through the Kenya Institute of Curriculum Development (KICD)) should come up with policies to ensure appropriate learning approaches which foster positive attitude towards learning.
\end{abstract}

Keywords: Constructivist Approach, Attitude, Constructivist Learning, Transmission, Transactional, Sitting Arrangements, Assignments, Evaluation

\section{Introduction}

Knowledge in biology is very critical for the society. The knowledge can be used to solve contemporary challenges in the society including animal and plant health [1]. In animal health, biological knowledge has been used to solve problems of overpopulation through the development of contraceptives as well as an understanding of the interdependence of organisms hence solving environmental degradation challenges. In plant health, biological knowledge has been used to solve problems of poor yields in agriculture as well as crop diseases [2]. Despite this, learner achievements in biology in secondary schools in Kenya have been poor. For instance, in the year 2010, Homa Bay County, with a total of 196 secondary schools had only 26 schools with a mean score of 6.4 and above in biology. This result was persistent in the years 2011 through to 2014. For instance, in the year 2011, the average mean score for biology in all the schools in the county was 5.707625. The 
poor performance is attributable to the poor attitude of the learners. This attitude is caused by the instructional method adopted by the instructor. According to the Kenya National Examinations Council reports for the years 2005 and 2010, poor performance was attributed to the conventional instructional methods characterized by lectures and few demonstrations [3]. The poor performance has been attributed to both teacher and student related factors as influenced by attitude towards the subject [4].

As a result of this, constructivist approach has been implemented in many classrooms [5]. The constructivist method of instruction is a method of instruction which allows learners to interact with their learning environment and participate in the construction of knowledge. According to reference [6], the pedagogical framework of constructivist theory challenges teachers to create innovative learning environment for students to think, explore and reflect on their ideas without fear. Students are active in selection of learning tasks and objectives for the lessons. The classroom teacher guides selection of learning activities to ensure it is challenging but intrinsically motivating to the students. Throughout the lesson, teacher collaborates with the pupils and he or she is readily available to provide material and information support to students. Learning materials focus on bigger ideas rather than facts and students are encouraged to follow their own interests to reach unique conclusions [7]. In the constructivist approach, assessment of learning outcome occurs as a continuous process. In this endeavour, both the teacher and the students are involved in the assessment of the learning outcome using students' portfolios, short quiz, and concept mapping. Assessment occurs within the learning context and feedback offered to the students is non-judge mental [7] [6].

The constructivist instructional method requires strategies that allow the learners to be part of the knowledge creation. Reference [8] outlined characteristics of constructivist instruction as involving goal setting and clear strategies of achieving the set goals. A constructivist teacher should have clear conceptual goals for the learners to attain from the instruction process and how the goals can be attained. The goals should also reflect high order thinking skills. The teaching and learning strategies employed by a constructivist teacher should identify and make use of the learners' pre-instructional knowledge. The instructional strategies should modify or change the learners' prior knowledge to reflect accepted ideas. This can be done by asking learners thought provoking questions that change their conceptual framework (Meyer, \& Land, 2013). A constructivist teacher should provide opportunities to the learners to utilize and transfer new ideas learned to new contexts. Lastly a constructivist teacher should provide learners with opportunities to perform learning tasks within the learners' relevant and realistic environment. All this implies that, during class activities and group discussions, learners can be allowed to make reference on textbooks and other learning resources. All the characteristics of constructivist instruction cited by [8] are similar to what reference [7] call the five pillars on which a constructivist classroom is built. The five pillars enumerated by Brooks and Brooks are herein mentioned and discussed briefly: The first pillar is posing emerging problems relevant to the learners. If learning tasks given to learners are relevant to them, the learners find transfer of learning easy and a change in the earlier held ideas is also readily accepted. Relevance in this case refers to the value the learners attach to the learning material. Second, structuring learning around primary concepts.

Teachers adopting the constructivist method of instruction should have an overview of the learning process so as to be able to present the learning materials in whole but not in parts. According to reference [9], learners can then make sense by breaking the whole into parts so that they understand how the parts relate to the whole. When learners break a whole into parts, learning is at analysis skill level which is a higher cognitive domain level. The teacher at this time should also be able to seek and value students' points of view. All learners have some pre-instructional knowledge they hold about the information to be learned and therefore the constructivist teacher needs to identify the learners' pre-instructional knowledge and elaborate on it to enable the learner formulate a new understanding and reconstruct new knowledge which is scientifically accepted [10]. Constructivist teachers can achieve this by acting as 'a guide on the side and not a sage on the stage' and he/she should be a good listener so as to get the learners' point of view.

The constructivist learning curriculum is based on methodologies that address suppositions in learning. Suppositions are ideas and belief that students hold as true but still need to be authenticated as true knowledge [11]. These suppositions can be considered as misconceptions that learners hold about the learning material presented. Constructivist teachers can address learners' suppositions by engaging in instructional strategies that engage in the first three pillars mentioned i.e. they asks questions of emerging relevance to the learners, structure learning materials around primary concepts, seek and value students' points of view [12]. The constructivist learning approach also involves assessment of learning in the context of teaching [13]. Assessment in the context of teaching implies assessment procedures carried out in the process of instruction. Such kind of assessment should involve observation of learners' work and all forms of interactions in the classroom environment.

\subsection{The 5 Es Constructivist Instructional Model}

The 5 E's model of instruction was proposed by Roger Bybee for the teaching of sciences in schools. The model was developed under the Biological Science Curriculum Study (BSCS) project. It's origin can be traced back to the mid-1980s, when BSCS received a grant from IBM to conduct a design study that would produce specifications for a new science and health curriculum for elementary schools [14]. The 5 'Es' instructional model is based on the five stages of learning namely; Engage, Explore, Explain, Elaborate and Evaluate. The model was designed to be an Inquiry Based Learning model and is based on the educational theory of 
Constructivism. It is based on the fact that learners need to build their own understanding of new ideas based on their prior experience and knowledge. They do this via explorations, testing out new ideas, asking questions, exploring options and rejecting incorrect assumptions, eventually constructing new knowledge and a new mental map that fits together and builds on their existing knowledge [15].

The approach begins with the engagement phase. The engagement stage is one of the activity stage which is meant to help the learner to make connections between past and present learning experiences. Engagement in the constructivist method has been defined as the involvement of the students in the pedagogically active process in the classroom or outside with an aim of getting computable results [16]. Similarly, reference [17] defines it as the level of student's involvement in various activities that is linked with learning outcomes. The engagement process therefore should help focus the students to become thoughtfully involved in the concept, process, or skill to be learned. The student is expected to relate to the problem being posed and be involved in finding a solution. The phase forms an integral part of the constructivist method bearing on the definition of constructivist instructional method as an active process of learning in which learners construct new ideas or concepts based upon their current and past knowledge [18]. The learner is therefore involved in encountering and processing information, formulation of hypotheses, and making decisions while relying on their cognitive structure. Reference [19] defines Cognitive structures as the basic mental processes people use to make sense of information. It is these Cognitive structures (i.e., schema, mental models) that reference [20] postulated to be involved in the provision of meaning and organization to experiences which allows the individual to move past supplied information. In this the constructivist instructional method has been credited as a successful pedagogical method which stimulates the enthusiasm in students and helps them deepen their understanding through experience [21]. It is the individual's experience that ultimately provides the meaning of learning opportunities [22].

At the exploration phase, the learners are expected to have a common base of experiences. The instructor adopts an open ended approach which allows the learners to identify and develop concepts, processes, and skills [23]. This allows the learners to actively explore their environment or manipulate materials during the learning process. By relying on the above approaches, the learners are able to establish real world connections, use materials and manipulative for hands-on interactions and providing a common base of experiences from which to grow and learn. In facilitating these interactions, a teacher should often pose problems to the learners that they would in turn explore in order to understand the truth within it [24]. To facilitate the exploration phase, the constructivist curriculum must be designed so that it reflects real life situations [25]. Towards this end, reference [26] proposed that social issues should be used as an organizer for the curriculum so as to contextualize the concepts taught in distinct and unique disciplines of study. Instructors in their distinct disciplines are expected to cross over the barriers between their disciplines and avoid sticking to the issues that are unique to their discipline. They are expected to integrate language, knowledge and process application so as to be able to lead students in creating real life situations in the process of acquiring knowledge. The instructors are also supposed to encourage research based activities at this phase of the instructional process. Research based programs give students the ability to retain facts through critical thinking by working through problems logically and making connections to the real world. In support of this, reference [20] advised that students should be allowed to know what it feels to be completely absorbed in a problem and that this experience is normally not experienced in schools where the conventional lecture methods are applied as a method of instruction.

In order to effectively guide learners in solving problems at this stage, the learners should be encouraged to seek answers to their own questions [27]. While exploring a concept, the learners should be given opportunities to work with materials and manipulative so that they can have experiences that are real and primary. This hands-on learning plays a crucial role in the constructivist instructional method, as it is the process of experiencing learning that is utilized in the exploration phase. When hand-on learning is facilitated during the instructional cycle, the learners experience so much fascinating content at their fingertips everywhere and this has been shown to be more effective given the affordability of technology today. Reference [28] posits that, in order to understand concepts better, instructors are advised to engage students in learning situations that effectively integrate their own experiences and familiar materials. For example, learners who enjoy bird hunting can be given opportunities to explore the concepts in population estimation methods and especially capturing organisms for the purposes of estimating their populations. They may also use perforated sacks as sweep nets to capture insects. This approach allows the learners to explore meaningful science topics set in the context of something they enjoy doing [24].

The explanation phase helps students uncover the content surrounding the concepts they have been exploring. Students should now have opportunities to verbalize their conceptual understanding, to encounter new content material or to demonstrate new skills [29]. This phase also provides opportunities for teachers to introduce primary content materials such as formal terms, definitions, and other content information. The implementation of this phase provides the learner with opportunities to identify skills and behaviour in order to both experience and discover content that may be useful in context [30]. Once the learners have opportunities to engage and explore a topic, which has the conceptual knowledge embedded within it, they can begin to have anchors of experience on which to fasten specific content knowledge. In constructivist terms, content delivery should focus on primary sources and materials in which content knowledge is applied and integrated. Sources can include textbooks, the Internet, mentors, film, lectures, or publications. Students should be directed to utilize the information they 
gather and encounter in ways that encourage them to analyse and synthesize. These behaviours, as well as interactions with the content, promote higher order, meaning is a human construction interacting with a social situation and therefore we define meaning for ourselves. The instructor therefore must regard the learner's point of view as something finally significant in themselves. Each learner understands content and concepts differently based on their previous experiences [31]. The students need opportunities to address their prior knowledge in order to address misconceptions and develop concepts correctly. In an effective classroom, learning requires more than connecting new material to old ways of thinking; rather, it requires students to arrive at new ways of understanding. Students come to school with their own ideas, some correct and some not, about almost every topic they are likely to encounter [32].

The explanation phase should also allow students to develop skills and behaviours that will help them to be successful in their learning. Students also need experiences that help them to develop new views and make better sense of their world [33]. If learning is the responsibility of the learner, it is also critical that the teacher guide the learning process with content materials and classroom experiences. Communication from and between multiple peoples and perspectives is important and vital in learning [34]. A person who successfully explains a body of knowledge to others may be said to have mastered this knowledge. In describing and explaining ideas to others, the learner synthesizes material in a way that requires higher-order thinking [35]. During explanation, teacher should encourage students to explain concepts in their own words, ask for evidence and clarification of their explanation, and listen critically to one another's explanation and those of the teacher. Students should use observations and recordings in their explanations [36]. At this stage teacher should provide definitions and explanations using students' previous experiences as a basis for this discussion.

The elaboration phase is designed to extend students' conceptual understanding in areas of skills and behaviours. In a constructivist framework, the educator provides opportunities in which learners can practice and refine their skills and behaviours in authentic contexts [37]. Students are also given multiple opportunities in order to deepen and broaden their knowledge base and integrate that knowledge into their conceptual understandings and actions, both inside and outside of the classroom. This instructional strategy allows the student to spend time exploring and explaining the process, with time for reflection and numerous experiences upon which to synthesize information [38]. According to reference [28], students should be engaged and participating both in and outside of class, as this is crucial to learning and the construction of purposes and meanings. The role of the teacher should be to actively promote and encourage positive group interactions and cooperative behaviours that foster thinking interactions that enhance the learning process [39]. At this stage, it is expected that the learning should move from insight to action, from content to concept and from a static situation to an ever-changing varying opportunities. This therefore requires intense problem-solving, cooperative learning and critical thinking. During the Elaboration phase, the students should be able to apply concepts and skills in new but similar situations and use formal labels and definitions. The teacher should remind the learners of the alternative explanations and to consider existing data and evidence as they explore new situations [14].

Evaluation phase both requires learners to assess their own understanding and abilities and allows the teacher to evaluate students' understanding of key concepts and skill development. As such, students learn to assess their own abilities, identify areas of mastery that they now possess, and strengthen developing understandings and [40]. This provides opportunities for the teacher to evaluate students' performance of new knowledge integration through presentations or demonstrations. Evaluation has been defined as methods utilized to clarify and understand the level of knowledge that a learner has obtained [41]. This broad definition implies that assessment methods can range from the simple to the complex, from a teacher's observations of students in class to an all-day standardized test (Tomlinson, 2014). The level of knowledge implies that what a student knows constantly changes over time, and that we as instructors can make judgments about student achievement [12].

\subsection{Learners' Attitude Towards Constructivist Learning Method}

Reference [42] define attitude as; "Any opinion or belief that includes an evaluation of some objects, person, or event along a continuum from negative to positive and that predispose us to act in certain ways towards that object, person or event" (p. 588). What is suggested here is that attitude influence a person's way of thinking, feeling and general behaviour. The attitude, feelings or opinion a student has on particular subject area, the subject teacher and the instructional approach adopted by the teacher has a big influence on what is learned [43]. Students who have positive attitude towards a subject tend to perform better than students who hold negative attitude. Reference [44] and [45] are in agreement that students' attitude can be manipulated in a learning environment to enhance achievement of the learning goals. Reference [45] refers to students' attitude as a "symptom of the prevailing classroom learning environment as created by the teaching approaches used by the teachers". (p. 78) and posits that in traditional classrooms dominated by lecture and few demonstrations, students' attitude are less positive compared to classrooms where interactive activities are prevalent. Constructivist learning methods create interactive classroom environment where students learn co-operatively, share feelings, and compare knowledge resulting into acquisition of high order thinking skills [46].

Reference [47] compared the learner attitude of two groups of students in constructivist and conventional instructional methods. In their study, the samples mean scores, standard deviation, percentages, and opinions on surveys were used to compare results for the students' attitude towards the two 
instructional methods. Their findings showed that there was a significant difference in student attitude towards the two instructional methods. Students had positive attitude towards the constructivist instructional methods than the conventional methods. In a study of learning biology, reference [48] found that high school students taught biology using constructivist method have positive attitudes towards biology as a subject. The students reasoned that hands- on- activities like projects, experiments, discussions, and use of models made them more interested in learning biology and provided them with skills to transfer in learning other subjects. The students also remarked that when biology is taught using lectures, lessons became long and boring. The present study adds a new dimension to the work of Donaldson by comparing the attitude boys and girls have towards constructivist instruction method in learning biology.

\subsection{Gender Differences in Learner Attitude Under Constructivist and Conventional Instructional Methods}

Gender difference refers to the socially constructed expectations of boys and girls. Gender describes the characteristics that a culture or a society desalinates as masculine or feminine [49]. These socially delineated expectations play a role in individual self-concept as well as aspirations and expectations in life [50]. It has been postulated that gender plays a role in learner achievement [51]. In other studies, attitude of learners has been indicated to be responsible for the difference in learner achievements across the two genders [52]. Available literature indicates that girls have positive attitude towards the constructivist learning environment as compared to boys. Reference [53] conducted a study comparing the perception of learning environment between boys and girls and concluded that girls had positive perception about the constructivist learning environment.

\subsection{Problem Statement}

Instructional approaches in science education have been undergoing a major transformation to accommodate learner-centred approaches in many countries around the world [54]. This has resulted into the promotion and some cases, the implementation of constructivist approaches. The main aim of this has been to address the problem of poor performance of secondary school students in national examination. While studies have indicated that the constructivist approach has improved the performance of learners in the science based curriculum across the world [55], learner attitude in the contextualized environment is factor predictive of its successful implementation.

\subsection{Purpose and Objectives}

The purpose of this study is to explore the learner attitude towards the constructivist approachin teaching biology. The study also aims at examining the difference in attitude between boys and girls towards the application of the constructivist approach in teaching biology. With this understanding, it is expected that the educationists will be able to gain a better understanding of the approach and gain the confidence in its application for successfully improving the confidence of learners towards the science based disciplines. Instructors can then make use of the study findings incoming up with appropriate measures of dealing with the attitude of the learners towards the instructional approaches which affect the learning outcome. The Ministry of Education, Science and Technology through the Kenya Institute of Curriculum Development (KICD) come up with policies to ensure appropriate learning approaches which foster positive attitude towards learning. Specifically, the study was conducted to explore the attitude of students towards the specific aspects of the constructivist instructional approach, to evaluate the overall attitude of learners towards the constructivist instructional approach and to determine the differences in attitude between girls and boys towards the constructivist instructional approach.

\subsection{Theoretical Context}

This study was guided by the social constructivist theory as proposed by Vygotsky. The theory view knowledge and truth as created not discovered by the mind [56]. According to the theory, concepts are constructed rather than discovered and yet they relate to something real in the world. Reference [57] also portend that reality is socially defined and that reality refers to the subjective experience of one's everyday life. Similarly, reference [58] also espoused that in reality, most of what is known and most of the knowing that is done should be concerned with trying to make sense of what it is to be human. So it is the individuals or groups of individuals and in our case, the learners who define the reality so constructed. For this to be realized, the constructivist instructor must create a context for learning in which students become engaged in interesting activities that encourages and facilitates learning. The instructor does not simply stand by, however, and watch children explore and discover. Instead, the instructor often guide students as they approach problems, encourages them to work in groups to think about issues and questions, and support them with encouragement and advice as they tackle problems, adventures, and challenges that are rooted in real life situations that are both interesting to the students and satisfying in terms of the result of their work. Teachers thus facilitate cognitive growth and learning as do peers and other members of the learner's community.

All classrooms in which instructional strategies compatible with Vygotsky's social constructivist approach are used don't necessarily look alike. The activities and the format can vary considerably. However, four principles are applied in any Vygotskian classroom; that learning and development is a social, collaborative activity; that the Zone of Proximal Development can serve as a guide for curricular and lesson planning; that school learning should occur in a meaningful context and not be separated from learning and knowledge children develop in the "real world." And those out-of-school experiences should be related to the child's school experience [59] 


\section{Conceptual Framework}

This study has been conceptualized with the 5Es constructivist instructional approach as the main independent variables while learner attitude forms the dependent variables. Figure 1 illustrates the conceptual framework.

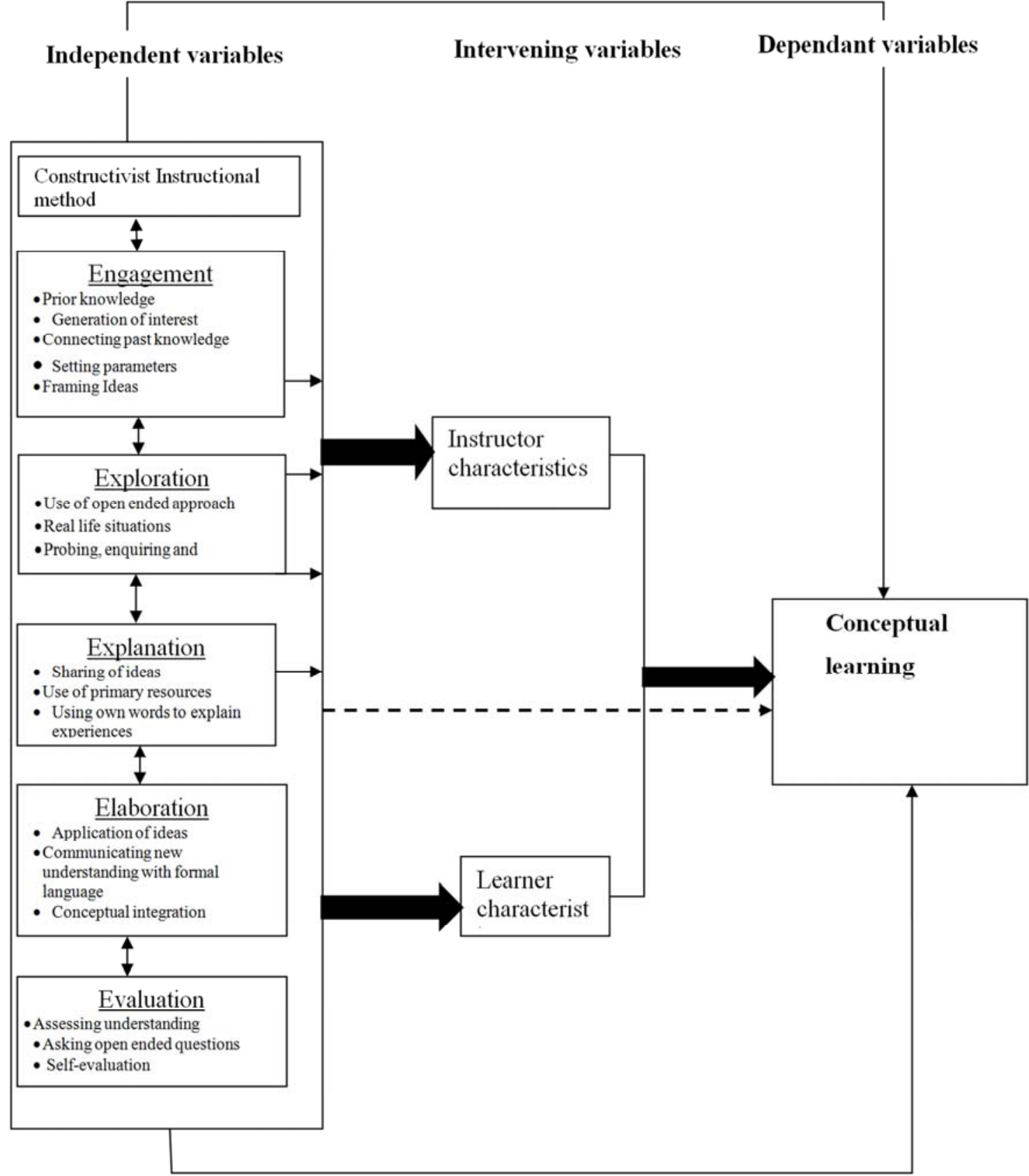

Figure 1. Conceptual framework.

\section{Methodology}

The study adopted cross sectional survey design. Participants in the study were drown from a total of 12 sampled schools (4 mixed schools, 4 boys' schools and 4 girl's schools). Participants were asked questions related to the constructivist approach of instruction and learning. The questions were in Likert form and tested the attitude of the students towards the constructivist method and its aspects. The study used descriptive statistics and statistical tests of significance to analyse and compare data from different treatment groups.

\section{Results}

The specific aspects of the constructivist instructional approach investigated were based on the 5 Esconstructivist model. Each section of attitude questionnaire was based on the five phases of the approach. Data presented is further divided according to the gender of the students and compared for significant difference. The items purposively selected for 
analysis were either strongly favouring constructivist or teacher-centred learning environments. The results are presented as percentages of participants who responded on the various scales of the response categories.

\subsection{Attitude Towards Evaluation of Basic Concepts}

The students' questionnaire had the following question testing on students' attitude towards teachers introducing lessons by asking questions from topics which have not been covered in class. Q4. A biology teacher should not introduce a lesson by asking questions on the topic he / she is yet to teach. Figure 2 presents responses of the participants' attitude towards the idea of teachers introducing lessons by asking questions on topics which have not been taught in class.

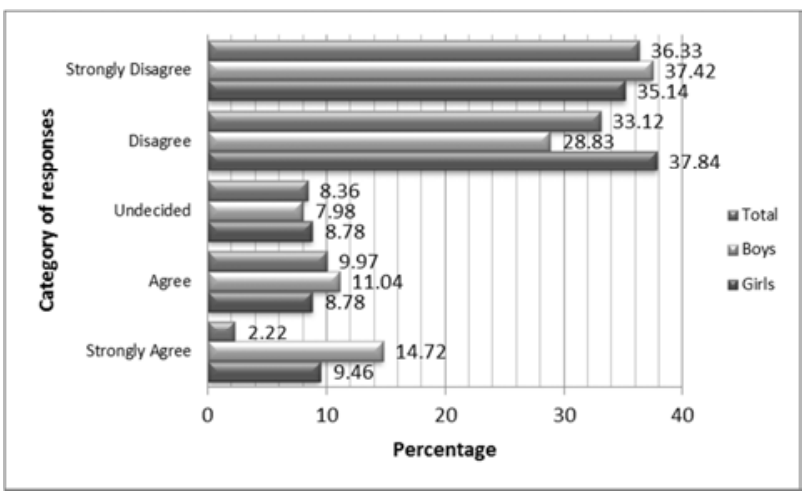

Figure 2. Students attitude towards evaluation of basic concepts.

The results presented in figure 2 indicates that $22.19 \%$ i.e. $(12.22 \%+9.17 \%)$ of the total participants were agreeing with the idea that teachers should not introduce a lesson by asking questions on topics yet to be taught while $69.45 \%$ of the total population were disagreeing with the idea thus indicating that teachers are free to ask such questions.

\subsection{Attitude Towards Sitting Arrangements}

Data on students' attitude towards sitting arrangements in a biology class was collected from participants' responses to the following question in the questionnaire: Q5. All the students in a biology class should sit facing the blackboard during all the class lessons. Figure 3 indicate responses of participants' attitude towards sitting arrangement in a biology class.

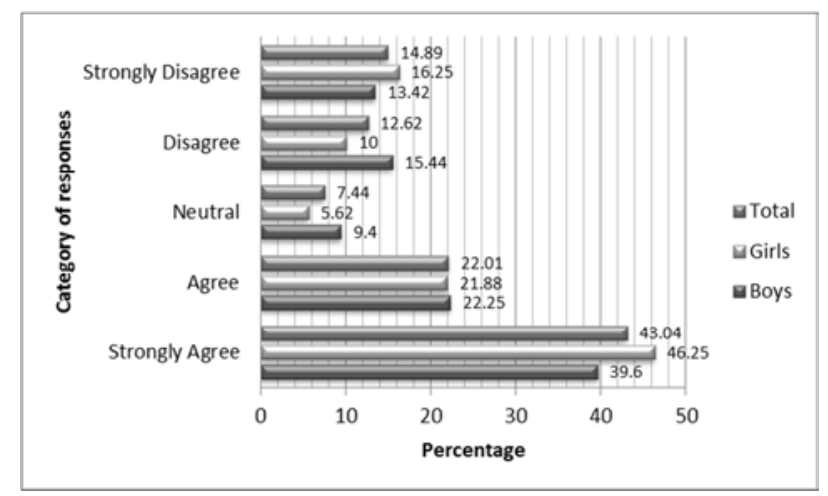

Figure 3. Attitude of students towards sitting arrangements.
The results in figure 3 indicate that $65.05 \%$ i.e. $(43.04+$ 22.01) of the total participants were agreeing with the idea that students in a biology class should always sit facing the blackboard while $17.51 \%$ were disagreeing with the idea. On comparing responses of girls and boys, it was found that $61.75 \%$ of girls and $68.10 \%$ of boys who participated in the study were agreeing that students should always sit facing the blackboard. At the same time, $28.86 \%$ of girls and $26.62 \%$ of boys were disagreeing. These results might imply that high school students always expect to sit facing the blackboard when in class. Facing the blackboard in class is the common way of siting in many classrooms [60]. It is a direct indication of transmission learning models taking place in many classrooms. In transmission learning' students acquire information transmitted through lectures, text books and few teacher demonstration [43]. In such scenario, students always sit when facing the blackboard with intension of reaping the maximum information from the teachers. The siting arrangement inhibits students from face to face contact and diminish learning [61].

Siting when facing the blackboard is a silent rule in many classrooms. Girls readily accomodate changes in classroom and particularly changes that favor collaborative learning experiences. In this study, the experimental group of participants sat facing the blackboard for only few minutes during the introduction of the lesson after which the participants settled into various class activities where they sat in groups facing each other to allow for collaborative learning amongst themselves.

\subsection{Attitude Towards Personal Relevance of Biology}

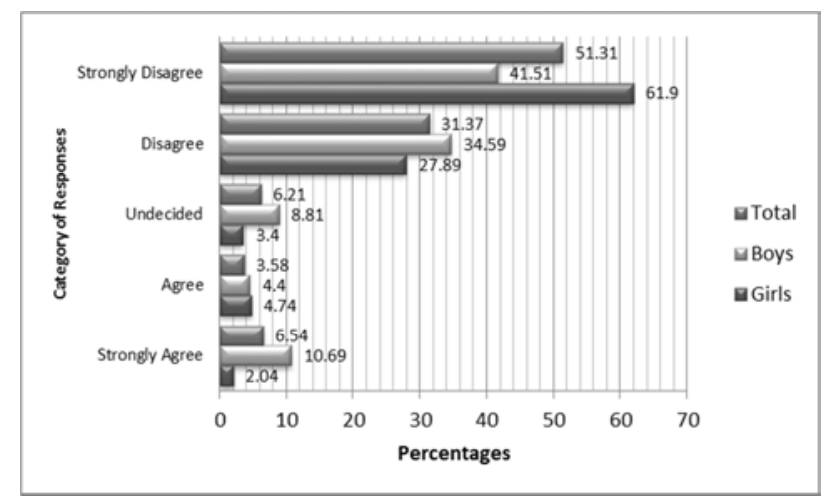

Figure 4. Attitude of students towards personal relevance of biology.

In order to find out students' attitude towards personal relevance of what they learn in biology to their life in and out of school, participants responded to the following question: Q7. What is learnt in biology is to enable students pass examinations only. Figure 4 indicates the results of responses of participants' attitude towards personal relevance to what is learnt in biology.

The results in figure 4 indicate that $11.12 \%$ of the total participants were agreeing with the idea that what is learned in biology class was only for passing examinations while $82.68 \%$ were disagreeing with the idea implying that most students find relevance and value of what is learned in biology 
as helping in understanding and solving problems in and out of school. In support of this, Prokop et al. (2007) found Slovak students to believe in importance of knowledge of biology but in contrast to Kenyan students, Slovak students do not consider knowledge of biology as useful and necessary to their daily life. On comparing the attitude of girls' and boys' towards this aspect of a learning environment, it was found that $6.8 \%$ of girls and $15.09 \%$ of boys were agreeing while $89.79 \%$ of girls and $76.10 \%$ of boys were disagreeing with the idea that biology they learn in school is only for passing examinations. These results indicate that girls seemingly have more relevance of what they learn in biology as useful to them in future life. Reference [62] states 'knowledge takes on added meaning when it can be used in real life situations..." (p. 111).

\subsection{Attitude Towards Nature of Assignments}

Data on students' attitude towards teachers giving assignments that require reference to library or community resources was collected from participants' responses to the following question: Q14. Biology teachers should always give assignments that require students to look for answer from library or from community resources. Figure 5 presents responses of participants' attitude towards students being referred to the library and community resources to do assignments.

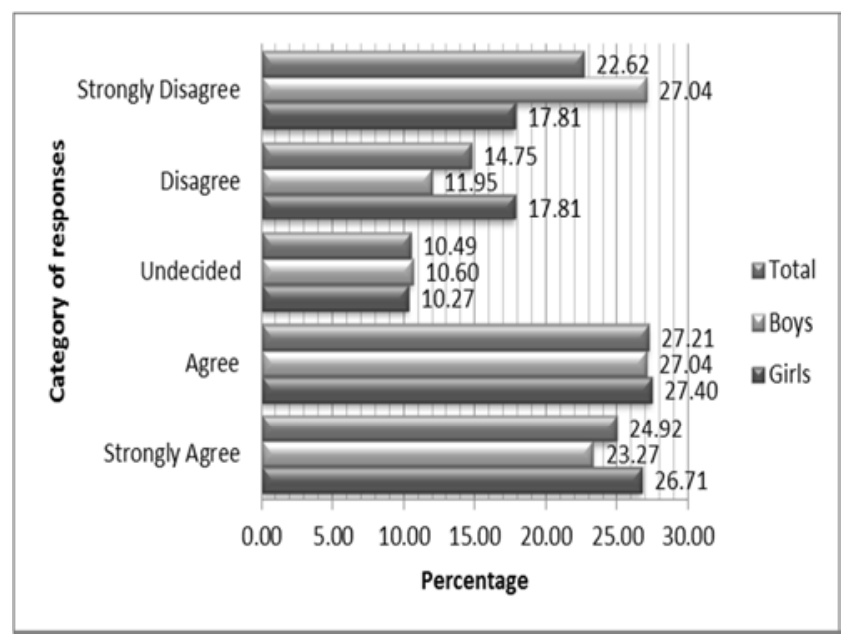

Figure 5. Attitude towards nature of assignments.

The results presented in figure 5 indicates that $52.13 \%$ of the total participants were agreeing with the idea that biology teachers should always give assignments that require students to seek answers from library or community resources while $37.37 \%$ were disagreeing with the idea. When girls' and boys' responses, was compared, it was found that $54.11 \%$ of girls and $50.13 \%$ of boys were agreeing with the idea while $35.62 \%$ of girls and $38.99 \%$ of boys were disagreeing with the idea. These results implied that girls, unlike boys seem to like the idea of being active and creative in the learning process. Girls also seem to like the idea of being responsible for their own learning. A greater percentage of participants in the study were agreeing with the idea of searching for answers to biology assignments from different resources in libraries and community resources. From the results, it was concluded that students seems to be interested in biology assignments that are thought provoking, require divergent reasoning and which can only be answered effectively from library and community resources. Searching for answers from library and community resources is an active and creative process, a phenomenon of constructivist learning theory. Assignments that require divergent reasoning allow teachers to assess students learning in the context of daily teaching experiences [28]. Reference [6] states that constructivist teachers should provide learning environments which are innovative, allow students to think and explore. Such assignment would naturally require students to explore different source in search for an answer. In addition, such questions are generally of high level and answering them involves critical and creative thinking, an indication of better understanding of concept [8]. Another implication of these results is that the students are in favour of classroom practices changing from direct teaching to students learning with little guidance from the teacher. Reference [63] states that traditional methods of teaching are not intellectual, they do not stimulate thinking and do not consider students diverse ideas.

\subsection{Attitude Towards Evaluation Process}

In order to find out the attitude of students towards evaluation of assignments by other students, participants responded to the following question in the questionnaire: Q15. In Biology class, students can be allowed to evaluate other students' work. Figure 6 presents participants' responses towards the evaluation process.

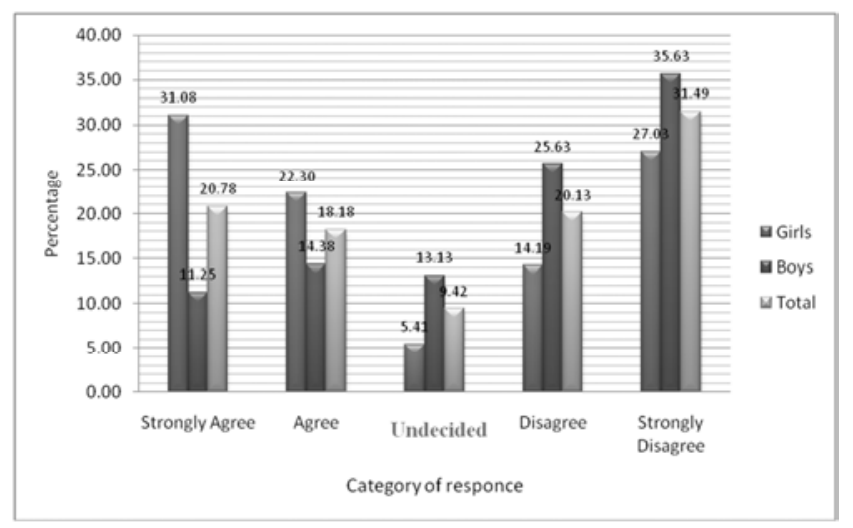

Figure 6. Students' attitude towards evaluation process.

The results in figure 6 indicates that $38.96 \%$ of the total participants agreed that in class students can be allowed to evaluate other students' work while $51.62 \%$ of the total participants were disagreeing with the idea. In comparing girls' and boys' responses, it was found that $53.38 \%$ of girls and $25.63 \%$ of boys were agreeing while $41.22 \%$ and $61.26 \%$ of girls and boys respectively were disagreeing. The undecided category was made up of total participants $(9.42 \%)$, girls $(5.41 \%)$ and boys $(13.13 \%)$. These results suggest that high school students dislike the idea of classmates or fellow students evaluating their assignments. When responses of girls 
and boys were compared, girls seem to be more tolerant to idea of evaluation by fellow students than boys. In a constructivist learning environment, students do assignments mostly in groups as they carry out investigations, discussions and presentations. Also when it comes to assessment of learning, group products are assessed by exhibitions and group presentations. These assessment procedures attract comments from all students in class, a practice which boys might not like. Girls who seem to be more tolerant to evaluation by fellow classmates have indeed embraced constructivist learning principles. Reference [7] argues that "differentiating between teaching and assessment is both unnecessary and counterproductive. Assessment through teaching, through participating in student/teacher interactions, through observing students/students interactions, and through watching students' work with ideas and materials tells us more about students learning than tests and externally developed assessment tasks"(p. 97).

Social constructivists recognise the social dimension of learning. Reference [64] opines that a learner's environment and the words used in learning process help in shaping the learner's understanding. The social dimension is provided when students have opportunity to discuss other students' work. Therefore boys who seem to dislike the idea of other students evaluating their work are in favour of transmission methods of teaching where assessment of learning activities is mostly separated from teaching and done mostly through testing using achievement tests. The achievement tests are very competitive because students primarily work on the tasks individually.

\subsection{Attitude of Students Towards Copying Notes}

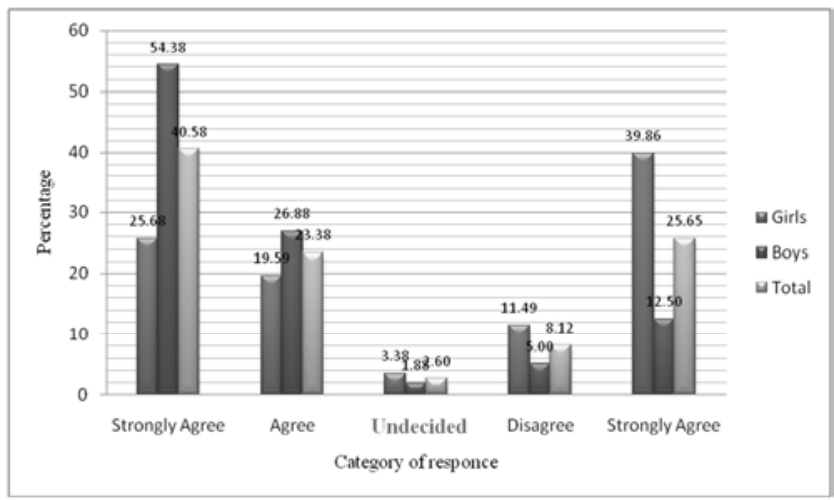

Figure 7. Students attitude towards copying of notes.

In order to find out the attitude of boys and girls towards copying notes from teachers, participants responded to the following question in the questionnaire: Q1. In biology class, teachers should give students elaborate notes to copy. Figure 7 indicates how the participants responded to the idea of teachers giving students notes to copy.

The responses in figure 7 indicates that $45.27 \%$ of girls and $81.26 \%$ of boys' who participated in the study were agreeing with the idea, while $51.35 \%$ of girls and $17.50 \%$ of boys who participated were disagreeing. Total participants who responded as undecided were $(2.6 \%)$, while girls and boys who were undecided are (3.38\%) and (1.88\%) respectively. In this aspect of learning environment it was concluded that most participants in the study agreed with the idea of teachers giving notes to students. Most boys participating in the study also agreed with the idea. However, for girls who participated most disagreed with the idea of teachers giving notes to students. These results indicate that boys are more in favour of teacher-cantered methods of instruction compared to girls. Boys favour teacher-cantered methods of instruction probably because lecture notes from teachers seem easier to revise and understand. This reasoning is supported by the work of reference [65] who concluded that learning of boys can be improved by providing highly structured lessons, detailed instruction, firm presentation with clearly stated objectives, while learning in most girls is supported by environments that provide opportunity for open ended activities, individuality in presentation and self-developed learning strategies.

\subsection{Overall Attitude of Students Towards the Constructivist Instructional Methods}

In order to ascertain the overall attitude of students towards the constructivist instructional methods, responses from all the students who took part in the constructivist and conventional methods of instruction and also responded to the attitude questionnaire were analysed. Analysed results were as follows; girls had a mean score and standard deviation of $(\mathrm{M}=58.30$; $\mathrm{SD}=9.15, \mathrm{~N}=150)$ while boys had a score of $(\mathrm{M}=53.14$; $\mathrm{SD}=8.24, \mathrm{~N}=146$ ). T-test runs on mean score differences for the groups revealed a significant difference between girls and boys attitude i.e. $\mathrm{t}(294)=5.18, \mathrm{p}<0.001$. The results were as presented in table 1 below.

Table 1. Attitude of Students towards the Constructivist Instructional Methods.

\begin{tabular}{lllll}
\hline Gender & Mean & Std. Dev. & t-value & p-value \\
\hline Girls $(\mathrm{N}=150)$ & 58.3 & 9.15 & \multirow{2}{*}{5.18} & $<0.001$ \\
Boys $(\mathrm{N}=146)$ & 53.14 & 8.24 & & \\
\hline
\end{tabular}

These findings led to the conclusion that Secondary school students have a positive attitude towards the constructivist instructional methods. Secondly, generally secondary school students are more positive towards use of constructivist method of instruction than the conventional method of instruction commonly used in biology class. This reasoning is based on the fact that considering the performance of boys' and that of girls', each of the two groups of participants scored over $50 \%$ in the attitude questionnaire, implying that both boys' and girls' like learning in environments where they have opportunity to actively participate in knowledge construction.

\section{Conclusions and Recommendations}

The findings of this study reveals that students have positive attitude towards the constructivist instructional methods and that girls were more positive towards the constructivist instructional methods as compared to the boys. 
This study therefore concludes that the constructivist instructional method is effective in improving learner achievements in biology and should therefore be adopted in secondary schools in teaching biology. It is recommended that instructors adopt the constructivist approach in learning so as to boost the attitude of students towards learning biology. It would also be appropriate for further investigations to be conducted in other fields of science such as chemistry and Physics so as to find out if the constructivist approach would also boost the attitude of students in such subjects. Finally, policy makers in the field of education in Kenya i.e. The Ministry of Education, Science and Technology through the Kenya Institute of Curriculum Development (KICD) come up with policies to ensure appropriate learning approaches which foster positive attitude towards learning.

\section{References}

[1] Brown, C. R. (2014). The Effective Teaching of School Biology. Routledge.

[2] Maundu, J. N., Sambili, H. J., \& Muthwii, S. M. (2005). Biology education: A methodological approach.

[3] Kenya National Examinations Council (KNEC). (2000-2013) Kenya Certificate of Secondary Education Examinations Report. Nairobi: Kenya Nationa Examinations Council.

[4] CEMASTEA, (2011). Effective resource mobilization, prioritization and utilization for quality education, Training Manual for Secondary Schools' Principals workshop, CEMASTEA, Nairobi.

[5] Fensham, P. J. (2004) Defining an Identity: The Evolution of Science Education as a Field of Research. Dordrecht, Netherlands: Kluwer Academic Publishers.

[6] Fosnot, C. T. (2005). Constructivism: Theory perspective and practice $\left(2^{\text {nd }}\right.$ ed) New York: Teachers College, press, Columbia University.

[7] Brooks, J. G. \& Brooks, M. G. (2001). In search of understanding: The case for Constructivist classrooms. New Jersey, Prentice Hall.

[8] Denton, D. W. (2012). Enhancing instruction through constructivism, cooperative learning, and cloud computing. TechTrends, 56 (4), 34-41.

[9] Schank, R. C., \& Abelson, R. P. (2013). Scripts, plans, goals, and understanding: An inquiry into human knowledge structures. Psychology Press.

[10] Brophy, J. E. (2013). Motivating students to learn. Routledge.

[11] Ewing, A. C. (2012). The Fundamental Questions of Philosophy (Routledge Revivals). Routledge.

[12] Earl, L. M. (2012). Assessment as learning: Using classroom assessment to maximize student learning. Corwin Press.

[13] Savery, J. R. (2015). Overview of problem-based learning: Definitions and distinctions. Essential Readings in Problem-Based Learning: Exploring and Extending the Legacy of Howard S. Barrows, 5.
[14] Baybee, R., Tayler, J., Gadner, R., Scotter, P., \& Powell, J. West brook, A., \& Lardes, N. (2006). The BSCS 5E Instructional Model: Origins, Effectives and Applications. Executive Summary BSCS.

[15] Yoon, J., \& Onchwari, J. A. (2006). Teaching young children science: Three key points. Early Childhood Education Journal, 33 (6), 419-423.

[16] Kuh, G. D. (2007). How to help students achieve. Chronicle of Higher Education, 53 (41), B12-13.

[17] Krause, K. L., \& Coates, H. (2008). Students' engagement in First - year University. Assessment \& Evaluation in Higher Education, 33 (5), 493-505.

[18] Driver, R., \& Oldham, V. (1986). A constructivist approach to curriculum development in science.

[19] Pratkanis, A. R., Breckler, S. J., \& Greenwald, A. G. (2014). Attitude structure and function. Psychology Press.

[20] Bruner, J. S. (1960). The Process of education. Cambridge, Mass.: Harvard University Press.

[21] Danielson, C. (2011). Enhancing professional practice: A framework for teaching. ASCD.

[22] Brown, J. S., Collins, A., \& Duguid, P. (1989). Situated cognition and the culture of learning. Educational researcher, $18(1), 32-42$.

[23] Hanke, R. (2009, January). Problem-based learning entrepreneurship education: a preliminary exploration. In United States Association for Small Business and Entrepreneurship. Conference Proceedings (p. 129). United States Association for Small Business and Entrepreneurship.

[24] Hirst-Loucks, C., \& Loucks, K. P. (2013). Serious Fun: Practical Strategies to Motivate and Engage Students. Routledge.

[25] Bentley, M. L. (1998). Constructivism as a referent for reforming science education. Constructivism and education, 233-249.

[26] Hofstein, A., \& Yager, R. E. (1982). Societal issues as organizers for science education in the ' $80 \mathrm{~s}$. School science and mathematics, 82 (7), 539-547.

[27] Boud, D., Keogh, R., \& Walker, D. (2013). Promoting reflection in learning a model. Boundaries of adult learning, 1, 32.

[28] Fink, L. D. (2013). Creating significant learning experiences: An integrated approach to designing college courses. John Wiley \& Sons.

[29] Loughran, J., Berry, A., \& Mulhall, P. (2012). Understanding and Developing Science Teachers' Pedagogical Content Knowledge (Vol. 12). Springer Science \& Business Media.

[30] Ergin, İ. (2012). Constructivist approach based 5E model and usability instructional physics. Latin-American Journal of Physics Education, 6 (1).

[31] Knowles, M. S., Holton III, E. F., \& Swanson, R. A. (2014). The adult learner: The definitive classic in adult education and human resource development. Routledge.

[32] Rutherford, F. J., \& Ahlgren, A. (1990). Science for All Americans. American Association for the Advancement of Science. Washington, Dc. 
[33] Boud, D. (Ed.). (2012). Developing student autonomy in learning. Routledge.

[34] Bentley, T. (2012). Learning beyond the classroom: Education for a changing world. Routledge.

[35] Brookfield, S. D. (2015). The skillful teacher: On technique, trust, and responsiveness in the classroom. John Wiley \& Sons.

[36] Hannafin, M. J., Hill, J. R., Land, S. M., \& Lee, E. (2014). Student-centered, open learning environments: Research, theory, and practice. In Handbook of research on educational communications and technology (pp. 641-651). Springer New York.

[37] Gregory, G. H., \& Chapman, C. (2012). Differentiated instructional strategies: One size doesn't fit all. Corwin Press.

[38] Quinn, D., Amer, Y., Lonie, A., Blackmore, K., Thompson, L., \& Pettigrove, M. (2012). Leading change: Applying change management approaches to engage students in blended learning. Australasian Journal of Educational Technology, 28 (1), 16-29.

[39] Prince, M. J., \& Felder, R. M. (2006). Inductive teaching and learning methods: Definitions, comparisons, and research bases. JOURNAL OF ENGINEERING EDUCATION-WASHINGTON-, 95 (2), 123.

[40] Plotnik, R., \& Kouyoumdjian, H. (2011). Introduction to psychology, $\left(9^{\text {th }}\right.$ ed). Mason, Ohio. Cengage Learning.

[41] Slavin, R. E. (2009). Educational psychology: Theory and practice $\left(9^{\text {th }} \mathrm{Ed}\right.$.) Columbus: Pearson Inc.

[42] Jurik, V., Gröschner, A., \& Seidel, T. (2013). How student characteristics affect girls' and boys' verbal engagement in physics instruction. Learning and instruction, 23, 33-42.

[43] Miheso-O'Conner, M. K. (2002). The relationship between interactive teaching and the acquisition of high order thinking skills in mathematics classroom. African Journal of Education Studies Vol. 1 Issue 1.

[44] Intel Corporation (2008). Intel teach program: Getting started course, participant Teacher edition Vol. 2.0.

[45] Becker, K., \& Maunsaiyat, S. (2004). A comparison of students' achievement and attitudes between constructivist and traditional classroom environments in Thailand vocational electronics programs. Journal of Vocational Education Research, 29 (2), 133-153.

[46] Donaldson, A. (2001). Biology exploration through technology: Taking the leap from theory to practice. Teach Treads (45): The H. W. Wilson Company.

[47] Stoltzfus, G., Nibbelink, B. L., Vredenburg, D., \& Hyrum, E. (2011). Gender, gender role, and creativity. Social Behavior and Personality: an international journal, 39 (3), 425-432.
[48] Rudman, L. A., \& Phelan, J. E. (2015). The effect of priming gender roles on women's implicit gender beliefs and career aspirations. Social psychology

[49] Jones, M. G., Howe, A., \& Rua, M. J. (2000). Gender differences in students' experiences, interests, and attitudes toward science and scientists. Science education, 84 (2), 180-192.

[50] Ongowo, Richard, Francis Indoshi, and Mildred Ayere. 'Perception of Constructivist Learning Environment: Gender and School Type Differences in Siaya County, Kenya'. AIR 4.1 (2015): 15-26. Web.

[51] Spring, J. (2008). Research on globalization and education. Review of Educational Research, 78 (2), 330-363.

[52] Taber, K. S. (2009). Progressing science education: Constructing the scientific research programme into the contingent nature of learning science (Vol. 37). Springer Science \& Business Media.

[53] Schwandt, T. A. (2003). Back to the Rough Ground!' Beyond Theory to Practice in Evaluation. Evaluation, 9 (3), 353-364.

[54] Berger, P. L., \& Luckmann, T. (1991). The social construction of reality: A treatise in the sociology of knowledge (No. 10). Penguin UK.

[55] Steedman, M. (2000). Information structure and the syntax-phonology interface. Linguistic inquiry, 31 (4), 649-689.

[56] Tudge, J. (1992). Vygotsky, the zone of proximal development, and peer collaboration: Implications for classroom practice.

[57] Straits, W. \& Wilke, R. (2007). How constructivist are we? Representation of transmission and participatory models of instruction in the journal of college science teaching. Journal of College Science Teaching (36) (7).

[58] Santrock, J. W. (2004). Educational psychology ( $2^{\text {nd }}$ ed) New York: McGraw-Hill.

[59] Airasian, P. W. (2000). Assessment in the classroom: A concise approach $\left(2^{\text {nd }}\right.$ ed). Boston, McGraw Hill Higher Education.

[60] Entwistle, N. J. (2013). Styles of learning and teaching: An integrated outline of educational psychology for students, teachers and lecturers. Routledge.

[61] Vygyotsky, L. S. (1978). Mind in society. The Development of High Psychological Process. Cambridge, M. A: Harvard University Press.

[62] Rudolf, D. W. (2012). Effect of outdoor education methods and strategies on student engagement in science: a descriptive study. 